\title{
Problem Teoritik Dan Implikasi Praktis Atas Perubahan Keputusan Tata Usaha Negara
}

\author{
Tohadi, Frieda Fania dan Dadang Gandhi \\ Fakultas Hukum Universitas Pamulang \\ Jln. Surya Kencana No. 1 Pamulang \\ mohtohadi@gmail.com; friedafania@gmail.com; dan dadanggandhi@yahoo.co.id
}

Received: 25 Agustus 2019; Accepted: 20 Januari 2020; Published: 17 Februari 2020

DOI: 10.20885/iustum.vol26.iss3.art4

\begin{abstract}
The change in the meaning of the State Administration Decree (KTUN) as stipulated in Article 87 of the Government Administration Act raises academic questions when the change had not been made through the amendment to the PTUN Law. This study discusses first, analysis on the change in the meaning of KTUN according to Law No. 30 of 2014 in terms of the theory of repeal and changes in legislation. Second, change in the meaning of KTUN according to Law No. 30 of 2014 in terms of the principles of the statutory rules. Third, implications of changing the meaning of KTUN according to Law No. 30 of 2014 against the absolute competence of PTUN. This is a normative study with qualitative analysis. The results of the study concluded, firstly, based on the theory of changes in legislation, the amendment to the provision of KTUN is not at all appropriate. Because it is done through a law that (the substantive content) is different. Second, the principles of statutory rules, namely lex specialis derogat legi generali, and lex posteriori derogat priori legi are not applicable to the enactment of Article 87 of Law No. 30 of 2014. Third, amendment to the provision of the KTUN according to Article 87 of Law No. 30 of 2014 has expanded the absolute authority of the PTUN to examine, to prosecute, and to decide the unlawful acts committed by the state officials that were previously the authority of the general court.
\end{abstract}

Keywords: KTUN; PTUN; Statutory Rules

\section{Abstrak}

Perubahan pengertian Keputusan Tata Usaha Negara (KTUN) sebagaimana diatur Pasal 87 UU Administrasi Pemerintahan menimbulkan pertanyaan akademik ketika perubahan itu tidak dilakukan melalui perubahan UU PTUN. Penelitian ini membahas: pertama, menganalisis perubahan pengertian KTUN menurut UU No. 30 Tahun 2014 ditinjau dari teori pencabutan dan perubahan peraturan perundang-undangan. Kedua, perubahan pengertian KTUN menurut UU No. 30 Tahun 2014 ditinjau dari asas-asas peraturan perundang-undangan. Ketiga, implikasi perubahan pengertian KTUN menurut UU No. 30 Tahun 2014 terhadap kompetensi absolut PTUN. Penelitian ini merupakan penelitian normatif dan analisis secara kualitatif. Hasil penelitian menyimpulkan, pertama, berdasarkan teori perubahan peraturan perundang-undangan, perubahan ketentuan KTUN tersebut tidak tepat. Karena dilakukan melalui undang-undang yang (materi muatannya) berbeda. Kedua, asas-asas peraturan perundang-undangan, yakni lex specialis derogat legi generali, dan lex posteriori derogat legi priori tidak dapat diberlakukan terhadap berlakunya Pasal 87 UU No. 30 Tahun 2014. Ketiga, perubahan ketentuan KTUN menurut Pasal 87 UU No. 30 Tahun 2014 memperluas kewenangan absolut PTUN yakni memeriksa, mengadili, dan memutus perbuatan melawan hukum yang dilakukan oleh penguasa yang sebelumnya menjadi kewenangan pengadilan umum.

Kata-kata Kunci: KTUN; PTUN; Perundang-undangan 


\section{Pendahuluan}

Lahirnya UU No. 30 Tahun 2014 tentang Administrasi Pemerintahan (disingkat UU No. 30 Tahun 2014) sejalan dengan semangat untuk mewujudkan tegaknya negara hukum Indonesia. Sebab, UU No. 30 Tahun 2014 ini dimaksudkan sebagai upaya untuk meningkatkan kualitas penyelenggaraan pemerintahan di mana badan dan/atau pejabat pemerintahan dalam menggunakan wewenang harus mengacu pada asas-asas umum pemerintahan yang baik dan berdasarkan ketentuan peraturan perundang-undangan. ${ }^{1}$ UU No. 30 Tahun 2014 khususnya Pasal 87 mengatur dan mengubah pengertian Keputusan Tata Usaha Negara (KTUN) atau beschikking yang ada dalam UU No. 5 Tahun 1986 tentang Peradilan Tata Usaha Negara sebagaimana telah diubah dengan UU No. 9 Tahun 2004 dan UU No. 51 Tahun 2009, khususnya Pasal 1 angka 3 UU No. 5 Tahun 1986 jo. Pasal 1 angka 9 UU No. 51 Tahun 2009.

Perubahan pengertian KTUN (beschikking) tersebut sebenarnya mempunyai sisi positif jika dilihat dari perlindungan hak warga masyarakat. Antara lain, adanya perubahan konstruksi atau rumusan hukum "Keputusan yang berpotensi menimbulkan akibat hukum" dari semula "yang menimbulkan akibat hukum" maka warga masyarakat dapat mengajukan keberatan melalui upaya administratif atau mengajukan gugatan tata usaha negara tanpa harus benar-benar terkena akibat hukum lebih dahulu dari suatu KTUN. Apabila sudah berpotensi menimbulkan akibat hukum, sudah cukup alasan bagi warga masyarakat untuk mengajukan keberatan melalui upaya administrasi atau mengajukan gugatan tata usaha negara melalui Pengadilan Tata Usaha Negara (PTUN). Hal demikian sangat sesuai dengan esensi utama dari PTUN. Esensi utama kehadiran PTUN adalah untuk menjaga harmoni antara kepentingan individu yang melekat dalam hak-hak warga negara dan memberikan kepastian hukum terhadap kepentingan publik yang pengelolaannya di bawah kontrol pemerintah. ${ }^{2}$

Keberadaan Peradilan Administrasi atau PTUN dituntut dapat menghasilkan suatu putusan yang bersifat menyelesaikan sehingga dapat memberikan pengayoman hukum dan kepastian hukum baik bagi rakyat maupun bagi

\footnotetext{
${ }^{1}$ Lihat Konsideran UU No. 30 Tahun 2014 tentang Administrasi Pemerintahan.

${ }^{2}$ Nicken Sarwo Rini, "Penyalahgunaan Kewenangan Administrasi Dalam Undang Undang Tindak Pidana Korupsi”, Jurnal Penelitian Hukum De Jure, Vol.18 No. 2, Juni 2018, hlm. 260.
} 
administrasi negara (badan atau pejabat tata usaha negara). Dengan kata lain harus mampu menciptakan keseimbangan kepentingan masyarakat dengan kepentingan individu. ${ }^{3}$ Dalam pandangan M. Guntur Hamzah, Guru Besar Hukum Administrasi Negara Fakultas Hukum Universitas Hasanudin, bahwa paradigma dalam UU No. 30 Tahun 2014 yang lebih menekankan pada partisipasi publik serta perlindungan warga negara dan pejabat pemerintah secara paralel dapat dikatakan sebagai bentuk pengembangan dari "administrative" model sebagaimana dikemukakan Javier Barnes.4 "Administrative" model merupakan versi hybrid dari prosedur yang merespon perubahan kebutuhan metode baru administrasi pemerintahan. Dalam model ini, berbagai kebijakan inovasi berusaha untuk menciptakan bentuk-bentuk partisipasi publik secara lebih efektif. Prosedur ini berlaku untuk pembuatan keputusan individual maupun aturan sebagai sarana untuk menyalurkan berbagai kebutuhan publik yang muncul dalam kebijakan publik modern. ${ }^{5}$

Perubahan pengertian KTUN (beschikking) menimbulkan pertanyaan akademik karena tidak dilakukan melalui perubahan UU tentang Peradilan Tata Usaha Negara, yaitu UU No. 5 Tahun 1986 tentang Peradilan Tata Usaha Negara sebagaimana telah diubah dengan UU No. 9 Tahun 2004 dan UU No. 51 Tahun 2009, melainkan dituangkan atau dicantumkan dalam UU No. 30 Tahun 2014 tentang Administrasi Pemerintahan. Dalam ilmu perundang-undangan, jika akan mengganti suatu UU atau ketentuan UU dilakukan melalui penggantian atau perubahan UU atau ketentuan UU. Hal ini dikenal teori pencabutan dan perubahan peraturan perundang-undangan. Di sisi lain, dalam asas hukum juga dikenal asasasas yang berkaitan dengan peraturan perundang-undangan untuk menjelaskan perubahan UU atau ketentuan UU. Yaitu, utamanya, asas peraturan perundangundangan yang menyatakan bahwa hukum yang lebih tinggi mengalahkan atau mengesampingkan hukum yang rendah (lex superior derogat legi inferiori), hukum

${ }^{3}$ Maridjo, “Analisis Penyelesaian Sengketa Tata Usaha Negara Mengenai Pemberhentian Kepala Desa di Pengadilan Tata Usaha Negara Semarang (Studi Kasus Putusan Pengadilan Tata Usaha Negara Semarang Nomor: 074/G/2015/PTUN-SMG)", Serat Acitya - Jurnal Ilmiab UNTAG Semarang, Vol. 5 No. 2, 2016, hlm. 32-33.

${ }^{4}$ M. Guntur Hamzah, "Paradigma Baru Penyelenggaraan Pemerintahan Berdasarkan Undang-Undang Administrasi Pemerintahan (Kaitannya dengan Perkembangan Hukum Acara Peratun)", Makalah disampaikan pada Seminar Sehari dalam rangka HUT Peradilan Tata Usaha Negara ke-26 dengan tema: Paradigma Baru Penyelenggaraan Pemerintahan Berdasarkan Undang-Undang Administrasi Pemerintahan, kaitannya dengan Perkembangan Hukum Acara Peratun, yang diselenggarakan di Hotel Mercure, Jakarta, 26 Januari 2016.

${ }^{5}$ Ibid. 
yang baru mengalahkan atau mengesampingkan hukum yang lama (lex posterior derogat legi priori), dan hukum yang khusus mengalahkan atau mengesampingkan hukum yang umum (lex specialis derogat legi generali). ${ }^{6}$

Berdasarkan hal tersebut, maka peneliti tertarik untuk meninjau perubahan pengertian KTUN dimaksud dari sisi teori pencabutan dan perubahan peraturan perundang-undangan maupun asas-asas peraturan perundang-undangan, dan implikasinya terhadap kompetensi absolut Pengadilan Tata Usaha Negara (PTUN).

\section{Rumusan Masalah}

Peneliti merumuskan masalah-masalah yang diteliti, sebagai berikut: pertama, bagaimanakah perubahan pengertian KTUN (beschikking) menurut UU No. 30 Tahun 2014 ditinjau dari teori pencabutan dan perubahan peraturan perundangundangan? Kedua, bagaimanakah perubahan pengertian KTUN (beschikking) menurut UU No. 30 Tahun 2014 ditinjau dari asas-asas peraturan perundangundangan? Ketiga, bagaimanakah implikasi perubahan pengertian KTUN (beschikking) menurut UU No. 30 Tahun 2014 terhadap kompetensi absolut PTUN?

\section{Tujuan Penelitian}

Penelitian ini bertujuan pertama untuk menganalisis perubahan pengertian KTUN (beschikking) menurut UU No. 30 Tahun 2014 ditinjau dari teori pencabutan dan perubahan peraturan perundang-undangan. Kedua, untuk menganalisis perubahan pengertian KTUN (beschikking) menurut UU No. 30 Tahun 2014 ditinjau dari asas-asas peraturan perundang-undangan. Ketiga, untuk menganalisis implikasi perubahan pengertian KTUN (beschikking) menurut UU No. 30 Tahun 2014 terhadap kompetensi absolut PTUN.

${ }^{6}$ Lihat M. Solly Lubis, Landasan dan Teknik Perundang-undangan, Cetakan Pertama, Alumni, Bandung, 1977, hlm. 125; Irawan Soejito, Teknik. Membuat Undang-Undang, Cet. 4, Pradnya Paramita, Jakarta, 1988, hlm. 112; Purnadi Purbacaraka dan Soerjono Soekanto, Perihal Kaedah Hukum, Citra Aditya Bakti, Bandung, 1993, hlm. 7-11; Amiroeddin Syarif, Perundang-undangan, Dasar, Jenis dan Teknik Membuatnya, Bina Aksara, Jakarta, 1987, hlm. 78-84; dan Sudikno Mertokusumo, Mengenal Hukum (Suatu Pengantar), Edisi Ketiga, Cetakan Pertama, Liberty, Yogyakarta, 1999, hlm. 72-74. 


\section{Metode Penelitian}

Penelitian ini merupakan penelitian normatif dengan melakukan penelitian kepustakaan atau data sekunder. ${ }^{7}$ Sifat penelitian ini merupakan penelitian deskriptif yang bertujuan menggambarkan secara lengkap ciri-ciri dari suatu keadaan, perilaku pribadi dan perilaku kelompok, serta untuk menentukan frekuensi suatu gejala. ${ }^{8}$

Penelitian ini menggunakan pendekatan peraturan perundang-undangan (statute approach) dan pendekatan konsep (concept approach). Konsep yang dianalisis khususnya mengenai KTUN. Sedangkan peraturan perundang-undangan yang digunakan sebagai alat analisis terutama, yaitu UU No. 5 Tahun 1986 tentang Peradilan Tata Usaha Negara sebagaimana telah diubah dengan UU No. 9 Tahun 2004 dan UU No. 51 Tahun 2009 serta UU No. 30 Tahun 2014 tentang Administrasi Pemerintahan.

Data yang digunakan dalam penelitian ini adalah data sekunder. Data sekunder terdiri dari bahan hukum primer, bahan hukum sekunder dan bahan hukum tersier. Bahan hukum primer merupakan bahan hukum yang mengikat, yakni semua aturan atau produk yang dibuat oleh badan legislatif, eksekutif, badan yudisial, seperti peraturan perundang-undangan, hukum adat, yurisprudensi dan traktat. Bahan hukum sekunder adalah bahan hukum yang memberikan penjelasan terhadap bahan hukum primer seperti rancangan undang-undang, buku teks, hasil penelitian, jurnal hukum, notulen, makalah, hasil seminar, bulletin, majalah hukum, hasil karya dari ahli hukum dan seterusnya. Bahan hukum tertier amerupakan bahan hukum yang memberikan petunjuk maupun penjelasan terhadap bahan hukum primer dan bahan hukum sekunder, misalnya ensiklopedia, indek kumulatif, bibliografi, daftar pustaka, katalog-katalog penerbitan, dan sebagainya. ${ }^{9}$ Alat pengumpulan data menggunakan studi dokumen. ${ }^{10}$

\footnotetext{
${ }^{7}$ Soerjono Soekanto dan Sri Mamudji, Penelitian Hukum Normatif Suatu Tinjauan Singkat, Rajawali Pers, Jakarta, 2004, hlm. 13.

${ }^{8}$ Soerjono Soekanto, Pengantar Penelitian Hukum, UI Press, Jakarta, 1982, hlm. 49, 53, dan 96.

${ }^{9}$ Lihat Soerjono Soekanto dan Sri Mamudji, Op. Cit., hlm. 13-14; Soerjono Soekanto, Op. Cit., hlm. 52; dan Soetandyo Wignjosoebroto, Hukum, Konsep dan Metode, Setara Press, Malang, 2013, hlm. 69-70.

${ }^{10}$ Soerjono Soekanto, Loc. Cit.
} 
Penelitian ini menggunakan analisis data atau analisis hasil secara kualitatif. Data-data awal terlebih dahulu akan diedit sehingga kesalahan-kesalahan dapat diperbaiki dan tidak ada keragu-raguan. Data-data kualitatif yang terkumpul dipisah-pisahkan menurut kategori masing-masing untuk kemudian ditafsirkan dalam usaha menjawab masalah penelitian. ${ }^{11}$

\section{Hasil Penelitian dan Pembahasan}

Perubahan Pengertian Keputusan Tata Usaha Negara (Beschikking) Menurut UU No. 30 Tahun 2014 Ditinjau dari Teori Pencabutan dan Perubahan Peraturan Perundang-undangan

Sebelum berlakunya ketentuan Pasal 87 UU No. 30 Tahun 2014 tentang Administrasi Pemerintahan, pengertian KTUN (beschikking) diatur dalam UU No. 5 Tahun 1986 tentang Peradilan Tata Usaha Negara jis. UU No. 9 Tahun 2004 tentang Perubahan Atas UU No. 5 Tahun 1986 tentang Peradilan Tata Usaha Negara dan UU No. 51 Tahun 2009 tentang Perubahan Kedua Atas UU No. 5 Tahun 1986 tentang Peradilan Tata Usaha Negara. Khususnya dalam Pasal 1 angka 3 UU No. 5 Tahun 1986 jo. Pasal 1 angka 9 UU No. 51 Tahun 2009.

Pasal 1 angka 3 UU No. 5 Tahun 1986 jo. Pasal 1 angka 9 UU No. 51 Tahun 2009 menyebutkan:

Keputusan Tata Usaha Negara adalah suatu penetapan tertulis yang dikeluarkan oleh badan atau pejabat tata usaha negara yang berisi tindakan hukum tata usaha negara yang berdasarkan peraturan perundang-undangan yang berlaku, yang bersifat konkret, individual, dan final, yang menimbulkan akibat hukum bagi seseorang atau badan hukum perdata.

Dalam Penjelasan Pasal 1 angka 3 UU No. 5 Tahun 1986 disebutkan dengan rinci, sebagai berikut:

Istilah "penetapan tertulis" terutama menunjuk kepada isi dan bukan kepada bentuk keputusan yang dikeluakan oleh Badan atau Pejabat Tata Usaha Negara. Keputusan itu memang diharuskan tertulis, namun yang disyaratkan tertulis bukanlah bentuk formalnya seperti surat keputusan pengangkatan dan sebagainya.

Persyaratan tertulis itu diharuskan untuk kemudahan segi pembuktian. Oleh karena itu sebuah memo atau nota dapat memenuhi syarat tertulis tersebut dan akan merupakan suatuu Keputusan Badan atau Pejabat Tata Usaha Negara menurut undang-undang ini apabila sudah jelas :

${ }^{11}$ Maria S.W. Sumardjono, Pedoman Pembuatan Usulan Penelitian, t.p., Yogyakarta, 1989, hlm. 24. 
a. Badan atau Pejabat Tata Usaha Negara mana yang mengeluarkannya;

b. maksud serta mengenai hal apa isi tulisan itu;

c. kepada siapa tulisan itu ditujukan dan apa yang ditetapkan di dalamnya.

Badan atau pejabat Tata Usaha Negara adalah Badan atau Pejabat di pusat dan daerah yang melakukan kegiatan yang bersifat eksekutif.

Tindakan hukum Tata Usaha Negara adalah perbuatan hukum Badan atau Pejabat Tata Usaha Negara yang bersumber pada suatu ketentuan hukum Tata Usaha Negara yang dapat menimbulkan hak atau kewajiban pada orang lain. Bersifat konkret, artinya objek yang diputuskan dalam Keputusan Tata Usaha Negara itu tidak abstrak, tetapi berwujud, tertentu atau dapat ditentukan, umpamanya keputusan mengenai rumah si A, izin usaha bagi si B, pemberhentian si A sebagai pegawai negeri.

Bersifat individual artinya Keputusan Tata Usaha Negara itu tidak ditujukan untuk umum, tetapi tertentu baik alamat maupun hal yang dituju. Kalau yang dituju itu lebih dari seorang, tiap-tiap nama orang yang terkena keputusan itu disebutkan. Umpamanya, keputusan tentang pembuatan atau pelebaran jalan dengan lampiran yang menyebutkan nama-nama orang yang terkena keputusan tersebut.

Bersifat final artinya sudah definitif dan karenanya dapat menimbulkan akibat hukum. Keputusan yang masih memerlukan persetu-juan instansi atasan atau instansi lain belum bersifat final karenanya belum dapat menimbulkan suatu hak atau kewajiban pada pihak yang bersangkutan. Umpamanya, keputusan pengangkatan seorang pegawai negeri memerlu-kan persetujuan dari Badan Adminitrasi Kepegawaian Negara.

UU No. 51 Tahun 2009 mengubah Pasal 1 angka 3 UU No. 5 Tahun 1986. Melalui UU No. 5 Tahun 2009 ini, pengertian KTUN diatur dalam Pasal 1 angka 9, sebagaimana disebutkan:

Keputusan Tata Usaha Negara adalah suatu penetapan tertulis yang dikeluarkan oleh badan atau pejabat tata usaha negara yang berisi tindakan hukum tata usaha negara yang berdasarkan peraturan perundangundangan yang berlaku, yang bersifat konkret, individual, dan final, yang menimbulkan akibat hukum bagi seseorang atau badan hukum perdata.

Jika dibaca ketentuan Pasal 1 angka 3 UU No. 5 Tahun 1986 dengan Pasal 1 angka 9 UU No. 51 Tahun 2009 tidak ada perubahan redaksi sama sekali. Namun Penjelasan Pasal 1 angka 9 UU No. 51 Tahun 2009 disebutkan “Cukup jelas”. Dengan demikian, untuk memahami unsur-unsur pengertian KTUN, maka dapat dibaca pada Penjelasan Pasal 1 angka 3 UU No. 5 Tahun 1986 jo. Pasal 1 angka 9 UU No. 51 Tahun 2009 yang menjelaskan unsur-unsur dari KTUN tersebut. 
Setelah berlakunya UU No. 30 Tahun 2014, KTUN mengalami perubahan. Mengenai pengertian KTUN disebutkan dalam Pasal 87 UU No. 30 Tahun 2014, yang berbunyi:

Dengan berlakunya UU No. 30 Tahun 2014 tentang Administrasi Pemerintahan ini, Keputusan Tata Usaha Negara sebagaimana dimaksud dalam Undang-Undang Nomor 5 Tahun 1986 tentang Peradilan Tata Usaha Negara sebagaimana telah diubah dengan Undang-Undang Nomor 9 Tahun 2004 dan Undang- Undang Nomor 51 Tahun 2009 harus dimaknai sebagai:

a. Penetapan tertulis yang juga mencakup tindakan faktual;

b. Keputusan Badan dan/atau Pejabat Tata Usaha Negara di lingkungan eksekutif, legislatif, yudikatif, dan penyelenggara negara lainnya;

c. Berdasarkan ketentuan perundang-undangan dan AUPB;

d. Bersifat final dalam arti lebih luas;

e. Keputusan yang berpotensi menimbulkan akibat hukum; dan/atau

f. Keputusan yang berlaku bagi warga masyarakat.

Dalam Penjelasan Pasal 87 huruf d UU No. 30 Tahun 2014 disebutkan, “Yang dimaksud dengan "final dalam arti luas" mencakup Keputusan yang diambil alih oleh Atasan Pejabat yang berwenang."

Pasal 87 UU No. 30 Tahun 2014 mengubah dan/atau memperluas makna KTUN yang dimaksud dalam UU No. 5 Tahun 1986 sebagaimana telah diubah dengan UU No. 9 Tahun 2004 dan UU No. 51 Tahun 2009 meliputi hal-hal:

(1) Penetapan tertulis yang juga mencakup tindakan faktual, dari sebelumnya sebagai penetapan tertulis;

(2) Keputusan Badan dan/atau Pejabat Tata Usaha Negara di lingkungan eksekutif, legislatif, yudikatif, dan penyelenggara negara lainnya, dari sebelumnya hanya di lingkungan eksekutif;

(3) Berdasarkan ketentuan perundang-undangan dan AUPB (Asas-Asas Umum Pemerintahan yang Baik), dari sebelumnya hanya berdasarkan ketentuan perundang-undangan;

(4) Bersifat final dalam arti lebih luas, dari sebelumnya hanya bersifat final;

(5) Keputusan yang berpotensi menimbulkan akibat hukum, dari sebelumnya keputusan yang menimbulkan akibat hukum;

(6) Keputusan yang berlaku bagi warga masyarakat, dari sebelumnya bagi seseorang atau badan hukum perdata.

Unsur-unsur KTUN pasca berlakunya UU No. 30 Tahun 2014 khususnya Pasal 87 terdiri dari hal-hal berikut ini:

(1) Penetapan tertulis termasuk tindakan faktual;

(2) Dikeluarkan oleh badan atau pejabat tata usaha negara di lingkungan eksekutif, legislatif, yudikatif, dan penyelenggara negara lainnya; 
(3) Berisi tindakan hukum tata usaha negara;

(4) Berdasarkan peraturan perundang-undangan dan AUPB (Asas-Asas Umum Pemerintahan yang baik);

(5) Bersifat konkret, individual, dan final dalam arti luas;

(6) Berpotensi menimbulkan akibat hukum; dan

(7) Berlaku bagi warga masyarakat.

Perbedaan Keputusan Tata Usaha Negara pasca berlakunya UU No. 30 Tahun 2014 digambarkan dalam tabel sebagai berikut:

Tabel

\section{Pasal 1 angka 3 UU No. 5}

Tahun 1986 jo. Pasal 1 angka 9 UU No. 51 Tahun 2009

(1) Penetapan tertulis;

(2) Dikeluarkan oleh badan

1) Penetapan tertulis termasuk tindakan atau pejabat tata usaha negara;

(3) Berisi tindakan hukum tata usaha negara; faktual;

Pasal 87 UU No. 30 Tahun 2014

(4) Berdasarkan peraturan perundang-undangan yang berlaku;

2) Dikeluarkan oleh badan atau pejabat tata usaha negara di lingkungan eksekutif, legislatif, yudikatif, dan penyelenggara negara lainnya;

3) Berisi tindakan hukum tata usaha negara;

4) Berdasarkan peraturan perundangundangan dan AUPB (Asas-Asas Umum

(5) Bersifat konkret, individual, Pemerintahan yang baik); dan final; dan

(6) Menimbulkan akibat

5) Bersifat konkret, individual, dan final dalam hukum bagi seseorang atau badan hukum perdata. arti luas;

6) Berpotensi menimbulkan akibat hukum; dan 7) Berlaku bagi warga masyarakat.

Ilmu perundang-undangan mengenal cara mengganti undang-undang atau ketentuan undang-undang, yaitu melalui pencabutan undang-undang dan perubahan undang-undang. ${ }^{12}$ Maria Farida Indrati membedakan pengertian pencabutan peraturan perundang-undangan dengan pengertian perubahan peraturan perundang-undangan. Oleh karenanya, pencabutan peraturan perundang-undangan bukan sebagai bagian dari perubahan peraturan perundang-undangan. ${ }^{13}$

Irawan Soejito menggunakan istilah "meniadakan suatu peraturan perundang-undangan". Menurutnya, setiap peraturan perundang-undangan umum (Undang-undang, Peraturan Pemerintah sebagai Pengganti Undang-

\footnotetext{
${ }^{12}$ Lihat Maria Farida Indrati S., Ilmu Perundang-undangan Proses dan Teknik Pembentukannya, Cetakan ke-5, Kanisius, Yogyakarta, 2011, hlm. 174-181

${ }^{13}$ Ibid., hlm. 174.
} 
undang dan Peraturan Pemerintah), baik yang sudah mulai berlaku, maupun yang belum, dapat ditiadakan, apabila:

1). Masalah yang diatur di dalamnya itu kemudian diatur kembali seluruhnya dalam suatu peraturan perundang-undangan umum baru;

2). Masalah yang diatur di dalamnya itu sudah tidak dipandang perlu lagi oleh

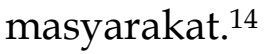

Dilihat dari ilmu perundang-undangan, sebagaimana dikemukakan Maria Farida Indrati dan Irawan Soejito, maka berlakunya UU No. 30 Tahun 2014 bukan dengan melakukan pencabutan, tetapi melakukan perubahan terhadap UU No. 5 Tahun 1986 jis. UU No. 9 Tahun 2004 dan UU No. 51 Tahun 2009. Karena dengan berlakunya UU No. 30 Tahun 2014 tidak berakibat terhadap tidak berlakunya UU No. 5 Tahun 1986 jis. UU No. 9 Tahun 2004 dan UU No. 51 Tahun 2009. Dengan adanya UU No. 30 Tahun 2014, maka tetap berlaku UU No. 5 Tahun 1986 jis. UU No. 9 Tahun 2004 dan UU No. 51 Tahun 2009.

Berlakunya ketentuan Pasal 87 UU No. 30 Tahun 2014 bukan melakukan pencabutan, tetapi melakukan perubahan terhadap ketentuan KTUN sebagaimana dimaksud dalam Pasal 1 angka 3 UU No. 5 Tahun 1986 jo. Pasal 1 angka 9 UU No. 51 Tahun 2009. Ketentuan Pasal 1 angka 3 UU No. 5 Tahun 1986 jo. Pasal 1 angka 9 UU No. 51 Rahun 2009 tetap berlaku. Hanya saja, ketentuan KTUN sebagaimana dalam Ketentuan Pasal 1 angka 3 UU No. 5 Tahun 1986 jo. Pasal 1 angka 9 UU No. 51 Tahun 2009 pengertiannya diubah dan/atau maknanya diperluas.

Berdasarkan teori perubahan peraturan perundang-undangan, bahwa perubahan suatu peraturan perundang-undangan dilakukan, apabila terdapat ketentuan-ketentuan dalam peraturan perundang-undangan tersebut yang tidak sesuai lagi dengan situasi atau kondisi yang berlaku dalam masyarakat. ${ }^{15}$ Menurut pendapat Irawan Soejito, mengubah adalah membuat sesuatu berbeda bentuknya dari bentuk yang semula, sehingga di dalam merubah termasuk pula menambah atau mengurangi, dan mengganti sebagian dari padanya. ${ }^{16}$ Lebih lanjut Irawan Soejito menyatakan perubahan itu dapat berupa:

\footnotetext{
${ }^{14}$ Irawan Soejito, Op. Cit., hlm. 111.

15 Ibid., hlm. 179.

${ }^{16}$ Irawan Soejito, Op. Cit., hlm. 145.
} 
a. menambah ketentuan baru, baik berbentuk bab, bagian, paragraf atau pasal baru, maupun ayat baru pada pasal lama;

b. mengubah bunyi pasal atau ayat lama;

c. menyisipkan suatu ketentuan atau perkataan;

d. menghapuskan bab, bagian, paragraf, pasal, ayat, kalimat, bagian kalimat atau perkataan tertentu; dan lain sebagainya. ${ }^{17}$

Menurut Maria Farida Indrati S., perubahan suatu peraturan perundangundangan dapat meliputi hal-hal sebagai berikut:

1. Menambah atau menyisipkan ketentuan baru, menyempurnakan atau menghapus ketentuan yang sudah ada, baik yang berbentuk bab, bagian, paragraf, pasal, ayat, maupun perkataan, angka, huruf, tanda baca dan lainlainnya.

2. Mengganti suatu ketentuan dengan ketentuan lain, baik yang berbentuk Bab, bagian, paragraf, pasal, ayat, maupun perkataan, angka, huruf, tanda baca dan lain-lainnya. ${ }^{18}$

Dalam mengadakan perubahan terhadap suatu peraturan perundangundangan, Maria Farida Indrati S., memberikan catatan hal-hal yang harus diperhatikan, yaitu:

a. Perubahan suatu peraturan perundang-undangan dilakukan oleh pejabat yang berwenang membentuknya, berdasarkan pada prosedur yang berlaku, dan dengan suatu peraturan perundang-undangan yang sejenis (atau setingkat).

b. Perubahan suatu peraturan perundang-undangan diharapkan dilakukan secara baik tanpa mengubah sistematika dari peraturan perundangundangan yang diubah.

c. Dalam suatu peraturan perubahan, perumusan judul hendaknya disebut peraturan perundang-undangan mana yang diubah dan untuk perubahan yang kedua kali dan selanjutnya disebutkan dengan jelas perubahan yang keberapa kalinya.

d. Dalam konsideran dari peraturan perundang-undangan yang diubah harus dikemukakan alasan-alasan atau pertimbangan-pertimbangan lainnya mengapa peraturan yang lama perlu diadakan perubahan.

e. Batang tubuh suatu peraturan perundang-undangan yang diubah hanya terdiri atas dua pasal yang ditulis dengan angka Romawi. Dalam kedua Pasal tersebut dimuat ketentuan sebagai berikut:

1) Pasal I memuat segala sesuatu perubahan, dengan diawali penyebutan peraturan perundang-undangan yang diubah, dan urutan perubahanperubahan tersebut hendaknya ditulis dengan angka Arab 1, 2, 3 dan selanjutnya. 
2) Pasal II memuat ketentuan mengenai mulai berlakunya peraturan perubahan tersebut.

f. Apabila suatu peraturan perundang-undangan sudah mengalami perubahan berulang kali, maka sebaiknya peraturan perundang-undangan tersebut dicabut dan diganti dengan peraturan perundang-undangan yang baru.

g. Apabila pembuat peraturan perundang-undangan berniat mengubah suatu peraturan perundang-undangan secara besar-besaran, maka demi kepentingan pemakai peraturan perundang-undangan tersebut dipandang lebih baik apabila dibentuk peraturan perundang-undangan yang baru. ${ }^{19}$

Berdasarkan teori perubahan peraturan perundang-undangan tersebut, mengubah pengertian dan/atau memperluas makna KTUN yang ada dalam ketentuan Pasal 1 angka 3 UU No. 5 Tahun 1986 jo. Pasal 1 angka 9 UU No. 51 Tahun 2009 dibenarkan. Namun demikian, hemat peneliti, perubahan tersebut selain harus dilakukan dengan suatu peraturan perundang-undangan yang sejenis (atau setingkat) dalam hal ini diubah dengan jenis dan tingkat yang sama yaitu undang-undang, juga harus dilakukan dalam undang-undang yang memuat materi yang sama (materi muatannya sama).

Sebagaimana telah dikemukakan oleh Maria Farida Indrati di atas, bahwa perubahan suatu peraturan perundang-undangan dilakukan oleh pejabat yang berwenang membentuknya, berdasarkan pada prosedur yang berlaku, dan dengan suatu peraturan perundang-undangan yang sejenis (atau setingkat). 20

Merujuk pada UU No. 12 Tahun 2011 tentang Pembentukan Peraturan Perundang-undangan (UU No. 12 Tahun 2011) pada Pasal 7 ayat (1), pengertian jenis dan tingkat (hierarki) peraturan perundang-undangan meliputi UndangUndang Dasar Negara Republik Indonesia (1945 UUD 1945), Ketetapan Majelis Permusyawaratan Rakyat (TAP MPR), Undang-Undang (UU)/Peraturan Pemerintah Pengganti Undang-Undang (Perpu), Peraturan Pemerintah (PP), Peraturan Presiden (Perpres), Peraturan Daerah Provinsi (Perda Provinsi), dan Peraturan Daerah Kabupaten/Kota (Perda Kabupaten/Kota). Selain itu, mengacu Pasal 8 ayat (1) UU No. 12 Tahun 2011, jenis Peraturan Perundang-undangan mencakup peraturan yang ditetapkan oleh MPR, DPR, DPD, MA, MK, BPK, KY,

\footnotetext{
${ }^{19}$ Maria Farida Indrati S., Ibid., hlm. 179-180.

${ }^{20}$ Maria Farida Indrati S., Ibid., hlm. 180.
} 
Bank Indonesia, Menteri, badan, lembaga, atau komisi yang setingkat yang dibentuk dengan Undang-Undang atau Pemerintah atas perintah UndangUndang, DPRD Provinsi, Gubernur, DPRD Kabupaten/Kota, Bupati/Walikota, Kepala Desa atau yang setingkat.

Pendapat Maria Farida Indrati S dikaitkan dengan ketentuan Pasal 7 ayat (1) dan Pasal 8 ayat (1) UU No. 12 Tahun 2011, menurut hemat peneliti, pasal tersebut menjelaskan bahwa perubahan undang-undang harus dilakukan dengan peraturan perundang-undangan yang sejenis, yaitu melalui undang-undang. Atau perubahan undang-undang harus dilakukan dengan peraturan perundangundangan yang setingkat, yaitu melalui undang-undang atau melalui Peraturan Pemerintah Pengganti Undang-Undang (Perppu). Perppu sesuai ketentuan Pasal 7 ayat (1) UU No. 12 Tahun 2011 merupakan peraturan perundang-undangan yang setingkat dengan UU.

Maria Farida Indrati mengemukakan bahwa dalam suatu peraturan perubahan, perumusan judul hendaknya disebut peraturan perundang-undangan mana yang diubah dan untuk perubahan yang kedua kali dan selanjutnya disebutkan dengan jelas perubahan yang keberapa kalinya. ${ }^{21}$ Pernyataan Maria Farida Indrati menurut hemat peneliti menunjukkan bahwa dalam perubahan peraturan perundang-undangan harus dilakukan, pertama, melalui peraturan perundang-undangan yang (materi muatannya) sama dan kedua, dengan merumuskan judul perubahan atas peraturan perundang-undangan perubahan tersebut untuk yang keberapa kalinya.

Hal tersebut dikuatkan dengan adanya ketentuan Pasal 5 huruf c UU No. 12 Tahun 2011 yang menyatakan bahwa dalam membentuk peraturan perundangundangan harus dilakukan berdasarkan pada asas pembentukan peraturan perundang-undangan yang baik, yang meliputi kesesuaian antara jenis, hierarki, dan materi muatan. Materi muatan dalam batang tubuh peraturan perundangundangan pada umumnya dikelompokkan ke dalam: a. ketentuan umum; b. materi

${ }^{21}$ Maria Farida Indrati S., Ibid., hlm. 180. 
pokok yang diatur; c. ketentuan pidana (jika diperlukan); d. ketentuan peralihan (jika diperlukan); dan e. ketentuan penutup. ${ }^{22}$

Perubahan ketentuan KTUN sebagaimana dalam Pasal 1 angka 3 UU No. 5 Tahun 1986 jo. Pasal 1 angka 9 UU No. Tahun 2009 yang dilakukan dengan pengaturan melalui Pasal 87 UU No. 30 Tahun 2014 adalah tidak tepat. Hal tersebut disebabkan perubahannya dilakukan melalui pengaturan undang-undang yang (materi muatannya) berbeda. Perubahan pengaturan mengenai KTUN dilakukan di dalam UU No. 30 Tahun 2014 tentang Administrasi Pemerintahan, bukan melalui perubahan selanjutnya dalam UU No. 5 Tahun 1986 tentang Peradilan Tata Usaha Negara yang mengatur pengertian KTUN sebelumnya.

UU No. 5 Tahun 1986 memuat materi pokok mengenai Peradilan Tata Usaha Negara, maka perubahan atas UU No. 5 Tahun 1986 harus dilakukan melalui UU yang memuat materi pokok yang sama dalam hal ini PTUN. Bukan dilakukan melalui UU yang memuat materi pokok yang berlainan dalam hal ini UU No. 30 Tahun 2014 yang memuat materi pokok mengenai Administrasi Pemerintahan.

\section{Perubahan Pengertian Keputusan Tata Usaha Negara (Beschikking) Menurut UU No. 30 Tahun 2014 Ditinjau dari Asas-Asas Peraturan Perundang-undangan}

Peneliti pada bagian ini menggunakan asas-asas peraturan perundangundangan untuk meninjau perubahan pengertian KTUN dan/atau perluasan maknanya atas ketentuan Pasal 1 angka 3 UU No. 5 Tahun 1986 jo. Pasal 1 angka 9 UU No. 51 Tahun 2009 menyusul berlakunya Pasal 87 UU No. 30 Tahun 2014. Asasasas tersebut diantaranya, yaitu asas peraturan perundang-undangan yang lebih tinggi mengalahkan yang lebih rendah (lex superior derogat legi inferiori), asas peraturan yang khusus akan melumpuhkan peraturan yang umum (lex specialis derogat legi generali), dan asas peraturan yang baru mengalahkan atau melumpuhkan peraturan yang lama (lex posteriori derogat legi priori). Namun, karena perubahan Pasal 1 angka 3 UU No. 5 Tahun 1986 jo. Pasal 1 angka 9 UU No. 51 Tahun 2009 dilakukan dengan peraturan perundang-undangan yang setingkat, yaitu melalui Pasal 87 UU No. 30 Tahun 2014, maka asas peraturan perundangundangan yang lebih tinggi mengalahkan yang lebih rendah (lex superior derogat

\footnotetext{
22 Lihat Lampiran II UU No. 12 Tahun 2011 mengenai Teknik Penyusunan Peraturan Perundangundangan, Bab I Kerangka Peraturan Perundang-Undangan, huruf C Batang Tubuh, angka 62
} 
legi inferiori) tidak dapat digunakan untuk menganalisis perubahan dan/atau perluasan pengertian KTUN tersebut.

Asas peraturan perundang-undangan yang mengatur peraturan yang khusus akan melumpuhkan peraturan yang umum sifatnya (lex specialis derogat legi generalis) diterapkan jika ada ketentuan yang bersifat khusus berlawanan dengan ketentuan yang bersifat umum. Dan ketentuan yang bersifat khusus-lah yang didahulukan berlakunya. Oleh karena pengaturan KTUN dalam Pasal 87 UU No. 30 Tahun 2014 secara kategoris tidaklah berlawanan, melainkan mengubah pengertian dan/atau memperluas maknanya, maka asas lex specialis derogat legi generalis tidak dapat diberlakukan untuk meniadakan berlakunya ketentuan Pasal 1 angka 3 UU No. 5 Tahun 1986 jo. Pasal 1 angka 9 UU No. 51 Tahun 2009.

Jika diundangkan peraturan baru yang tidak mencabut peraturan yang lama yang mengatur materi yang sama, sedangkan kedua-duanya saling bertentangan satu sama lain, maka peraturan yang baru mengalahkan atau melumpuhkan peraturan yang lama. Ini dinamakan asas lex posteriori derogat legi priori.

Mengenai adanya ketentuan Pasal 87 UU 30/2014 ini, H.M. Laica Marzuki, berpendapat:23

Secara mutatis mutandis, hanya perlu diadakan penyesuaian (aanpassing) terhadap UU No. 30 Tahun 2014 dimaksud sepanjang berkaitan dengan kekhususan prosedural daripadanya.

Asas lex posterior derogat legi priori (= undang-undang yang datang kemudian menyampingkan undang-undang terdahulu) tidak relevan dengan pemberlakuan UU No. 30 Tahun 2014.

Menurut M. Laica Marzuki, ${ }^{24}$ bahwa dengan berlakunya UU No. 30 Tahun 2014, maka ketentuan yang ada pada UU No. 5 Tahun 1986 jis. UU No. 9 Tahun 2004 dan UU No. 51 Tahun 2009 hanya perlu menyesuaikan (aanpassing) dengan ketentuan yang ada pada UU No. 30 Tahun 2014. Pemberlakuan UU No. 30 Tahun 2014, menurutnya, tidak menyampingkan UU No. 5 Tahun 19861986 jis. UU No. 9

23 M. Laica Marzuki, "Pemberlakuan Undang-Undang Nomor 30 Tahun 2014 tentang Administrasi Pemerintahan dalam Konteks Perkembangan Kompetensi Peradilan Tata Usaha Negara RI”, dalam http://ptunjakarta.go.id/wp-content/uploads/file/makalah narasumber hut peratun 2017/prof dr hm laica marzuki sh/Pemberlakuan $\% 20$ UU $\% 20$ NO. $\% 2030 \% 20$ Tahun $\% 202014 \% 20$ Tentang $\% 20$ Administrasi $\% 20$ Pem erintahan\%20.pdf, diakses tanggal 10 Mei 2017.

$$
{ }^{24} \text { Ibid. }
$$


Tahun 2004 dan UU No. 51 Tahun 2009. Dengan demikian, asas lex posteriori derogat legi priori tidak dapat diberlakukan. Peneliti sependapat dengan M. Laica Marzuki, bahwa terkait pengaturan ketentuan KTUN dalam Pasal 87 UU No. 30 Tahun 2014 tidak dimaksudkan untuk meniadakan ketentuan KTUN dalam UU No. 5 Tahun 1986 jis. UU No. 9 Tahun 2004 dan UU No. 51 Tahun 2009 khususnya Pasal 1 angka 3 UU No. 5 Tahun 1986 jo. Pasal 1 angka 9 UU No. 51 Tahun 2009.

Berdasarkan paparan di atas dapat ditarik kesimpulan bahwa asas-asas peraturan perundang-undangan, yakni asas peraturan perundang-undangan yang lebih tinggi mengalahkan yang lebih rendah (lex superior derogat legi inferiori), asas peraturan yang khusus akan melumpuhkan peraturan yang umum (lex specialis derogat legi generali), dan asas peraturan yang baru mengalahkan atau melumpuhkan peraturan yang lama (lex posteriori derogat legi priori) tidak dapat diberlakukan untuk meninjau secara akademik berlakunya Pasal 87 UU No. 30 Tahun 2014 terhadap ketentuan Pasal 1 angka 3 UU No. 5 Tahun 1986 jo. Pasal 1 angka 9 UU No. 51 Tahun 2009. Secara prinsip, berlakunya Pasal 87 UU No. 30 Tahun 2014 tidak meniadakan, melainkan hanya mengubah pengertian dan/atau memperluas makna ketentuan KTUN yang ada dalam Pasal 1 angka 3 UU No. 5 Tahun 1986 jo. Pasal 1 angka 9 UU No. 51 Tahun 2009 tersebut.

\section{Implikasi Perubahan Pengertian Keputusan Tata Usaha Negara (Beschikking) Menurut UU No. 30 Tahun 2014 Terhadap Kompetensi Absolut Pengadilan Tata Usaha Negara}

Merujuk pada pengertian KTUN atau beschikking sebagaimana dalam UU No. 5 Tahun 1986 jis. UU No. 9 Tahun 2004 dan UU No. 51 Tahun 2009 khususnya Pasal 1 angka 3 UU No. 5 Tahun 1986 jo. Pasal 1 angka 9 UU No. 51 Tahun 2009 dihubungkan dengan ketentuan Pasal 1 angka 4 UU No. 5 Tahun 1986 jo. Pasal 1 angka 10 UU No. 51 Tahun 2009, maka kompetensi absolut PTUN adalah memeriksa, mengadili, dan memutus sengketa tata usaha negara (sengketa TUN).

Pasal 1 angka 3 UU No. 5 Tahun 1986 jo. Pasal 1 angka 9 UU No. 51 Tahun 2009 menyatakan:

Sengketa Tata Usaha Negara adalah sengketa yang timbul dalam bidang tata usaha negara antara orang atau badan hukum perdata dengan badan atau pejabat tata usaha negara, baik di pusat maupun di daerah, sebagai akibat 
dikeluarkannya keputusan tata usaha negara, termasuk sengketa kepegawaian berdasarkan peraturan perundang-undangan yang berlaku.

Merujuk pada ketentuan di atas, orang atau badan hukum perdata yang kepentingannya dirugikan oleh suatu KTUN, maka yang bersangkutan mengajukan hak gugat pada PTUN.

KTUN di sini sebagaimana dimaksud Pasal 1 angka 3 UU No. 5 Tahun 1986 jo. Pasal 1 angka 9 UU No. 51 Tahun 2009 dan telah diulas sebelumnya, memiliki unsur-unsur:

(1)Penetapan tertulis;

(2)Dikeluarkan oleh badan atau pejabat tata usaha negara;

(3)Berisi tindakan hukum tata usaha negara;

(4)Berdasarkan peraturan perundang-undangan yang berlaku;

(5)Bersifat konkret, individual, dan final; dan

(6)Menimbulkan akibat hukum bagi seseorang atau badan hukum perdata

Namun demikian, jika yang merugikan kepentingan orang atau badan hukum perdata tersebut berupa tindakan faktual, bukan penetapan tertulis, dari badan atau pejabat tata usaha negara, maka bukanlah merupakan komptenensi absolut dari PTUN. Melainkan komptensi absolut pengadilan umum atau Pengadilan Negeri (PN). Jadi, jika ada perbuatan melawan hukum yang dilakukan oleh penguasa atau badan atau pejabat tata usaha negara (onrechtmatige overheids daad) yang merugikan orang atau badan hukum perdata harus diajukan pada PN.

Seiring dengan adanya ketentuan Pasal 87 UU No. 30 Tahun 2014 yang mengubah pengertian KTUN sebagaimana dalam ketentuan Pasal 1 angka 3 UU No. 5 Tahun1986 jo. Pasal 1 angka 9 UU No. 51 Tahun 2009 a quo, maka kompetensi absolut dari PTUN mengalami perubahan atau perluasan.

Hemat peneliti, ada dua hal pokok perubahan atau perluasan kompetensi absolut PTUN sebagai implikasi dari perubahan dan/atau perluasan pengertian KTUN dimaksud. Pertama, kompetensi absolut PTUN tidak hanya memeriksa, mengadili dan memutus sengketa keputusan administrasi pemerintahan atau KTUN, tetapi juga termasuk memeriksa, mengadili dan memutus sengketa tindakan administrasi pemerintahan. Hal ini oleh karena unsur "penetapan tertulis" dalam pengertian KTUN sebelumnya berubah dan diperluas menjadi 
"termasuk tindakan faktual". Jika ada tindakan faktual dari penguasa atau badan atau pejabat tata usaha negara yang melawan hukum atau merugikan kepentingan seseorang atau badan hukum perdata (onrechtmatige overheids daad), maka merujuk pada ketentuan Pasal 87 UU No. 30 Tahun 2014 kini menjadi kompetensi absolut PTUN dari sebelumnya menjadi kompetensi absolut PN.

Sejalan dengan pendapat peneliti, Dola Riza menyatakan apabila dibandingkan, UU No. 30 Tahun 2014, memperluas objek sengketa tata usaha negara yakni dengan menjadikan perbuatan materiil (materiele daad) sebagai bagian dari pengertian keputusan tata usaha negara, sehingga tidak hanya terbatas dalam ranah pembuatan, penerbitan dan keabsahan keputusan tata usaha negara, melainkan juga telah memasukkan tindakan faktual (materiil) dalam rangka pelaksanaan keputusan tata usaha negara dalam menjalankan fungsi pemerintahan. ${ }^{25}$ Dengan maksud yang sama, Kartika Widya Utama berpendapat, dalam UU No. 30 Tahun 2014, terdapat upaya memperluas kewenangan PTUN, yang tidak hanya terbatas dalam ranah pembuatan, penerbitan dan keabsahan Keputusan/Surat Keputusan Tata Usaha Negara melainkan juga telah memasukkan tindakan faktual (materiil) dalam rangka pelaksanaan keputusan tata usaha negara dalam menjalankan fungsi pemerintahan. ${ }^{26}$ Dan menurutnya, perluasan kewenangan ini sesuai dengan tujuan dibentuknya PTUN sebagai sarana kontrol hukum yang utuh di bidang administrasi pemerintahan. ${ }^{27}$

Yodi Martono Wahyunadi berpendapat, bahwa PTUN menangani obyek berupa tindakan administrasi pemerintahan (Pasal 1 angka 8 UU No. 30 Tahun 2014) yang semula diuji oleh pengadilan di lingkungan peradilan umum melalui Perbuatan Melawan Hukum oleh Pejabat (PMHP) menggunakan Pasal 1365 KUH Perdata. ${ }^{28}$ Selain adanya obyek sengketa baru berupa tindakan faktual, menurut Yodi, dengan adanya UU No. 30 Tahun 2014 (bukan hanya karena perubahan

\footnotetext{
${ }^{25}$ Dola Riza, "Keputusan Tata Usaha Negara Menurut Undang-Undang Peradilan Tata Usaha Negara dan Undang-Undang Admnistrasi Pemerintahan”, Jurnal Bina Mulia Hukum, Volume 3, Nomor 1, September 2018, hlm. 94.

${ }^{26}$ Lihat Pasal 1 angka 1 jo. Pasal 87 huruf a UU No. 30 Tahun 2014.

${ }^{27}$ Kartika Widya Utama, "Surat Keputusan Tata Usaha Negara Yang Bersifat Fiktif Positif”, Jurnal Notarius, Edisi 08 Nomor 2 September (2015), hlm. 145-146.

28 Yodi Martono Wahyunadi, "Kompetensi Absolut Pengadilan Tata Usaha Negara Dalam Konteks Undang-Undang Nomor 30 Tahun 2014 tentang Administrasi Pemerintahan” Jurnal Hukum dan Peradilan, Volume 5, Nomor 1, Maret 2016, hlm. 141.
} 
pengertian KTUN), kompetensi PTUN menilai unsur penyalahgunaan wewenang (Pasal 21 UU No. 30 Tahun 2014) dan memeriksa permohonan keputusan fiktif positif (Pasal 53 UU No. 30 Tahun 2014), serta kompetensi PTUN terhadap keputusan pejabat atau badan pemerintahan hasil upaya administratif sebagaimana diatur dalam Pasal 76 ayat (3) UU No. 30 Tahun 2014. ${ }^{29}$

Implikasi kedua, kompetensi absolut PTUN memeriksa, mengadili dan memutus baik KTUN maupun tindakan administrasi pemerintahan yang tidak hanya dilakukan oleh badan atau pejabat tata usaha negara di lingkungan eksekutif, tetapi juga badan atau pejabat tata usaha negara di lingkungan eksekutif, legislatif, yudikatif, dan penyelenggara negara lainnya. Ini sebagai konsekuensi perubahan dan/atau perluasan pengertian KTUN sebagaimana disebutkan dalam Pasal 87 UU No. 30 Tahun 2014.

\section{Penutup}

Berdasarkan pada hasil dan pembahasan penelitian di atas, dapat ditarik kesimpulan sebagai berikut. Pertama, dilihat dari ilmu perundang-undangan, berlakunya ketentuan Pasal 87 UU No. 30 Tahun 2014 bukan melakukan pencabutan, tetapi melakukan perubahan terhadap ketentuan KTUN sebagaimana dimaksud dalam Pasal 1 angka 3 UU No. 5 Tahun 1986 jo. Pasal 1 angka 9 UU No. 51 Tahun 2009. Dilihat dari sisi teori perubahan peraturan perundang-undangan tersebut, perubahan ketentuan KTUN sebagaimana dalam Pasal 1 angka 3 UU No. 5 Tahun 1986 jo. Pasal 1 angka 9 UU No. 51 Tahun 2009 yang dilakukan dengan pengaturan melalui Pasal 87 UU No. 30 Tahun 2014 adalah tidak tepat. Karena dilakukan pengaturannya melalui undang-undang yang (materi muatannya) berbeda dalam hal ini UU No. 30 Tahun 2014, bukan melalui perubahan selanjutnya dalam UU No. 5 Tahun 1986.

Kedua, asas-asas peraturan perundang-undangan, yakni asas peraturan perundang-undangan yang lebih tinggi mengalahkan yang lebih rendah (lex superior derogat legi inferiori), asas peraturan yang khusus akan melumpuhkan peraturan yang umum (lex specialis derogat legi generali), dan asas peraturan yang baru mengalahkan 
atau melumpuhkan peraturan yang lama (lex posteriori derogat legi priori) tidak dapat diberlakukan untuk meninjau secara akademik berlakunya Pasal 87 UU No. 30 Tahun 2014 terhadap ketentuan Pasal 1 angka 3 UU No. 5 Tahun 1986 jo. Pasal 1 angka 9 UU No. 51 Tahun 2009. Sebab, secara prinsip, berlakunya Pasal 87 UU No. 30 Tahun 2014 tidak meniadakan, melainkan hanya mengubah pengertian dan/atau memperluas makna ketentuan KTUN yang ada sebeleumnya dalam Pasal 1 angka 3 UU No. 5 Tahun 1986 jo. Pasal 1 angka 9 UU No. 51 Tahun 2009.

Ketiga, kompetensi absolut Pengadilan Tata Usaha Negara mengalami perubahan. Seiring adanya perubahan ketentuan KTUN menurut Pasal 87 UU No. 30 Tahun 2014 tersebut, maka kompetensi absolut PTUN mencakup juga memeriksa, mengadili, dan memutus perbuatan melawan hukum yang dilakukan oleh penguasa (onrechtmatige overheids daad) yang sebelumnya menjadi kompetensi pengadilan umum atau Pengadilan Negeri (PN).

Merujuk pada hasil dan pembahasan penelitian serta kesimpulan yang telah diuraikan di atas, peneliti perlu memberikan saran-saran, yaitu satu, pembentuk undang-undang dalam hal ini Dewan Perwakilan Rakyat (DPR) dan Presiden harus segera melakukan sinkronisasi khususnya mengenai ketentuan KTUN yang ada pada UU No. 5 Tahun 1986 jis. UU No. 9 Tahun 2004 dan UU No. 51 Tahun 2009 dengan yang ada pada Undang-Undang No. 30 Tahun 2014. Dua, terkait hal di atas, perlu segera dilakukan perubahan terhadap UU No. 5 Tahun 1986 jis. UU No. 9 Tahun 2004 dan UU No. 51 Tahun 2009 maupun UU No. 30 Tahun 2014 khususnya mengenai ketentuan KTUN dan yang terkait dengannya. Tiga, jika belum dapat dilakukan bersamaan, maka harus didahulukan adanya perubahan atas UU No. 5 Tahun 1986 jis. UU No. 9 Tahun 2004 dan UU No. 51 Tahun 2009 terutama Pasal 1 angka 3 UU No. 5 Tahun 1986 jo. Pasal 1 angka 9 UU No. 51 Tahun 2009 untuk melakukan penyesuaian (aanpassing) terhadap UU No. 30 Tahun 2014 terutama Pasal 87.

\section{Daftar Pustaka}

\section{Buku}

Farida Indrati S., Maria, Ilmu Perundang-undangan Proses dan Teknik Pembentukannya, Kanisius, Yogyakarta, 2011.

Lubis, M. Solly, Landasan dan Teknik Perundang-undangan, Alumni, Bandung, 1977. 
Mertokusumo, Sudikno, Mengenal Hukum (Suatu Pengantar), Liberty, Yogyakarta, 1999.

Purbacaraka, Purnadi dan Soekanto, Soerjono, Perihal Kaedah Hukum, Citra Aditya Bakti, Bandung, 1993.

Soejito, Irawan, Teknik Membuat Undang-Undang, Pradnya Paramita, Jakarta 1988.

Soekanto, Soerjono, Pengantar Penelitian Hukum, UI Press, Jakarta, 1982.

dan Sri Mamudji, Penelitian Hukum Normatif Suatu Tinjauan Singkat, Rajawali Pers, Jakarta, 2004.

Sumardjono, Maria S.W., Pedoman Pembuatan Usulan Penelitian, t.p., Yogyakarta, 1989.

Syarif, Amiroeddin, Perundang-undangan, Dasar, Jenis dan Teknik Membuatnya, Bina Aksara, Jakarta, 1987.

Wignjosoebroto, Soetandyo, Hukum, Konsep dan Metode, Setara Press, Malang, 2013.

\section{Jurnal}

Maridjo, "Analisis Penyelesaian Sengketa Tata Usaha Negara Mengenai Pemberhentian Kepala Desa di Pengadilan Tata Usaha Negara Semarang (Studi Kasus Putusan Pengadilan Tata Usaha Negara Semarang Nomor: 074/G/2015/PTUN-SMG)", Serat Acitya - Jurnal Ilmiah UNTAG Semarang, Vol. 5 No. 2, 2016.

Rini, Nicken Sarwo, “Penyalahgunaan Kewenangan Administrasi Dalam Undang Undang Tindak Pidana Korupsi", Jurnal Penelitian Hukum De Jure, Vol.18 No. 2, Juni 2018.

Riza, Dola, "Keputusan Tata Usaha Negara Menurut Undang-Undang Peradilan Tata Usaha Negara dan Undang-Undang Admnistrasi Pemerintahan", Jurnal Bina Mulia Hukum, Volume 3, Nomor 1, September 2018.

Utama, Kartika Widya, "Surat Keputusan Tata Usaha Negara Yang Bersifat Fiktif Positif", Jurnal Notarius, Edisi 08 Nomor 2 September (2015).

Wahyunadi, Yodi Martono, “Kompetensi Absolut Pengadilan Tata Usaha Negara Dalam Konteks Undang-Undang Nomor 30 Tahun 2014 tentang Administrasi Pemerintahan", Jurnal Hukum dan Peradilan, Volume 5, Nomor 1, Maret 2016.

\section{Makalah/Pidato}

M. Guntur Hamzah, “Paradigma Baru Penyelenggaraan Pemerintahan Berdasarkan Undang-Undang Administrasi Pemerintahan (Kaitannya dengan Perkembangan Hukum Acara Peratun)", makalah disampaikan pada Seminar Sehari dalam rangka HUT Peradilan Tata Usaha Negara ke26 dengan tema: Paradigma Baru Penyelenggaraan Pemerintahan Berdasarkan Undang-Undang Administrasi Pemerintahan, kaitannya dengan Perkembangan 
Hukum Acara Peratun, yang diselenggarakan di Hotel Mercure, Jakarta, 26 Januari 2016.

\section{Internet}

HM. Laica Marzuki, “Pemberlakuan Undang-Undang Nomor 30 Tahun 2014 tentang Administrasi Pemerintahan dalam Konteks Perkembangan Kompetensi Peradilan Tata Usaha Negara RI", diakses melalui http://ptun-jakarta.go.id/wp-content/uploads/file/makalah_ narasumber_hut_peratun_2017/prof_dr_hm_laica_marzuki_sh/Pemberla kuan\%20UU\%20NO.\%2030\%20Tahun\%202014\%20Tentang\%20Administr asi\%20Pemerintahan\%20.pdf, tanggal 10 Mei 2017.

\section{Peraturan Perundang-Undangan}

Undang-Undang Nomor 5 Tahun 1986 tentang Peradilan Tata Usaha Negara, Lembaran Negara Republik Indonesia Tahun 1986 Nomor 77; Tambahan Lembaran Negara RI Nomor 3344.

Undang-Undang Nomor 9 Tahun 2004 tentang Perubahan Atas Undang-Undang Nomor 5 Tahun 1986 Tentang Peradilan Tata Usaha Negara; Lembaran Negara Republik Indonesia Tahun 2004 Nomor 35, Tambahan Lembaran Negara RI Nomor 4380.

Undang-Undang Nomor 51 Tahun 2009 tentang Perubahan Kedua Atas UndangUndang Nomor 5 Tahun 1986 Tentang Peradilan Tata Usaha Negara; Lembaran Negara Republik Indonesia Tahun 2009 Nomor 160, Tambahan Lembaran Negara RI Nomor 5079.

Undang-Undang Nomor 12 Tahun 2011 tentang Pembentukan Peraturan Perundang-undangan, Lembaran Negara Republik Indonesia Tahun 2011 Nomor 82; Tambahan Lembaran Negara RI Nomor 5234.

Undang-Undang Nomor 30 Tahun 2014 tentang Administrasi Pemerintahan, Lembaran Negara Republik Indonesia Tahun 2014 Nomor 292; Tambahan Lembaran Negara RI Nomor 5601. 